\title{
KARAKTERISTIK ALELOPATI EKSTRAK DAUN JARAK PAGAR (Jatropha curcas L.) TERHADAP PERTUMBUHAN KECAMBAH JAGUNG HIBRIDA (Zea mays L.) VARIETAS BISI 18
}

\author{
Rengga Adyatma ${ }^{1}$, Martha Lulus Lande ${ }^{2}$, Zulkifli $^{3}$, Sri Wahyuningsih ${ }^{4}$ \\ 1,2, 3,4 FMIPA Biologi Universitas Lampung \\ Email: rengga.adyatma.m2m@gmail.com
}

Diterima : 15 Oktober 2018. Disetujui: 22 Novemver 2018. Dipublikasikan: 29 Desember 2018

\begin{abstract}
Abstrak
Penelitian ini bertujuan untuk mengetahui apakah ekstrak daun jarak pagar dapat menghambat pertumbuhan jagung hibrida varietas bisi 18 , serta untuk mengetahui variabel mana yang lebih sensitif terhadap pengaruh ekstrak air daun jarak pagar. Penelitian ini menggunakan metode Rancangan Acak Lengkap (RAL) dengan 5 taraf konsentrasi ekstrak air daun jarak pagar yaitu 0\% b/v (kontrol) $5 \% \mathrm{~b} / \mathrm{v} 10 \% \mathrm{~b} / \mathrm{v} 15 \% \mathrm{~b} / \mathrm{v} 20 \% \mathrm{~b} / \mathrm{v}$ dengan 5 kali ulangan. Variabel yang diamati dalam percobaan ini adalah panjang tunas, berat segar dan berat kering kecambah, kadar air relatif, dan kandungan klorofil $a, b$, dan total. Data hasil penelitian ini dianalisis ragam pada taraf 5\% jika hasilnya berpengaruh maka di lanjutkan dengan uji BNT pada taraf nyata 5\%. Hasil penelitian menunjukan bahwa ekstak daun jarak pagar konsentrasi $20 \%$ menurunkan panjang tunas dan berat kering secara signifikan kecambah jagung hibrida varietas bisi 18. Dari hasil penelitian ini dapat disimpulkan bahwa ekstrak daun jarak pagar mempengaruhi panjang tunas dan berat kering, tetapi tidak mempengaruhi berat segar kecambah, kadar air relatif, rasio tunas akar dan klorofil jagung hibrida varietas bisi 18 .
\end{abstract}

Kata kunci : Alelopati, jagung hibrida,Jarak Pagar, varietas bisi 18

\begin{abstract}
This research aims to find out whether Jatropha leaf extract can inhibit the growth of hybrid corn of Bisi 18 variety, and to find out which variables are more sensitive to the effect of Jatropha leaf water extract. This study used a Completely Randomized Design (CRD) method with 5 levels of distance of Jatropha leaf extract concentration, namely $0 \% \mathrm{~b} / \mathrm{v}$ (control) $5 \% \mathrm{~b} / \mathrm{v} 10 \% \mathrm{~b} / \mathrm{v} 15 \%$ $b / v 20 \% b / v$ with 5 times repeat. The variables observed in this experiment were shoot length, fresh weight and sprout dry weight, relative water content, and chlorophyll $a, b$, and total content. The data from this study analyzed the variance at the level of $5 \%$ if the results were influential then proceed with the LSD test at the 5\% level. The results showed that the extract of Jatropha leaves $20 \%$ concentration significantly reduced the length of shoots and dry weight sprouth of hybrid corn of Bisi 18 variety. From the results of this study it can be concluded that Jatropha leaf extract affects the length of shoots and dry weight, but does not affect the fresh weight of sprouts, relative water content, ratio of root shoots and chlorophyll content of bisi 18 variety.
\end{abstract}

Keywords: Alelophaty, bisi 18 variety, hybrid corn, jatropha curcas, 


\section{PENDAHULUAN}

Tanaman jarak pagar (Jatropha curcas L.) termasuk famili Euphorbiaceae yang berasal dari daerah tropik Amerika, dan saat ini sedang dikembangkansebagai tanaman alternatif penghasil biodisel (Raden dkk. 2008).

Namun demikian, beberapa peneliti menduga bahwa tanaman jarak pagar memiliki senyawa alelokimia yang dapat menghambat pertumbuhan tanaman. Grainge dan Armed menyatakan bahwa semua bagian tanaman jarak pagar memiliki bahan kimia yang berkhasiat sebagai insektisida (Raden dkk. 2008). Lebih lanjut, Garcia dan Lawas menyatakan bahwa ekstrak air daun jarak pagar efektif dalam mengontrol Sclerotium sp. dan pathogen fungi Azolla (Raden dkk. 2008). Selanjutnya, menyatakan bahwa biji jarak bersifat toksik, oleh karena itu ampas biji jarak pagar tidak dapat digunakan untuk makanan ternak karena beracun. Penelitian Heller membuktikan bahwa pemberian ampas biji 5 ton/ha menghambat perkecambahan benih tomat (Heller 1996).

Alelopati dapat dihasilkan dari gulma, tanaman semusim, tumbuhan berkayu, residu tanaman, dan mikroorganisme merupakan salah satu jenis gulma penting di daerah tropik basah yang dapat menghambat pertumbuhan dan produksi tanaman, antara lain jagung (Zea maysL.) (Junaedi, CHOZIN, dan Kim 2006). Tanaman jagung merupakan tanaman pangan penghasil karbohidrat potensial kedua di Indonesia setelah beras. Selain itu, jagung juga merupakan bahan baku industri dan pakan ternak, pemanis pengganti gula tebu, bahan baku pembuat biofuel, dan lain-lain. Kebutuhan jagung di Indonesia untuk konsumsi meningkat sekitar 5,16\% pertahun sedangkan untuk kebutuhan pakan ternak dan bahan baku industri naik sekitar 10,87\% pertahun (Rosmarkam dan Yuwono 2002).

\section{METODE PENELITIAN}

Penelitian ini dilaksanakan di Laboratorium Botani, Jurusan Biologi, Fakultas Matematika dan Ilmu PengetahuanAlam, Universitas Lampung dari bulan November sampai Desember 2018. Penelitian ini menggunakan metode Rancangan Acak Lengkap (RAL) dengan 5 taraf konsentrasi ekstrak air daun jarak pagar yaitu $0 \% \mathrm{~b} / \mathrm{v}$ (kontrol) 5\% b/v 10\% b/v 15\% b/v 20\% b/v dengan 5 kali ulangan. Variabel yang diamati dalam percobaan ini adalah panjang tunas, berat segar dan berat kering kecambah, kadar air relatif, dan kandungan klorofil $a, b$, dan total. 
Parameter dalam penelitian ini adalah semua nilai tengah $(\mu)$ variabel pertumbuhan kecambah. 100 gram daun jarak dikering anginkan selama \pm 7 hari. Daun dihaluskan dengan blender sampai diperoleh serbuk kering daun jarak pagar. Serbuk diayak dengan saringan sehingga diperoleh serbuk kering daun jarak pagar yang homogen. Agar memperoleh konsentrasi ekstrak daun jarak pagar yang dibutuhkan untuk perlakuan dilakukan pelarutan serbuk dalam aquades sesuai konsentrasi yang diinginkan.

Seleksi benih dilakukan dengan merendam benih dalam akuades selama 10 menit. Benih jagung yang mengapung dan sampah dibuang, sedangkan benih yang tenggelam diambil untuk dikecambahkan. Benih yang telah diseleksi selanjutnya direndam dalam larutan ekstrak daun jarak pagar selama 24 jam dengan konsentrasi $0 \%$ b/v 5\% b/v 10\% b/v 15\% 20\%. Benih jagung yang telah direndam dalam larutan ekstrak daun jarak pagar dikecambahkan dalam 5 nampan plastik yang telah dilapisi dengan tisu dan kertas saringan yang sudah dibasahi aquades.Setiap nampan masing-masing konsentrasi di isi 100 butir benih. Jumlah total benih yang digunakan adalah 500 butir benih tiap percobaan. Perhitungan jumlah benih dilakukan selama 7 hari penaburan.

Berdasarkan satuan percobaan, jumlah gelas plastik yang digunakan sebagai wadah penanaman benih yang telah berkecambah adalah sebanyak 25 buah. Gelas plastik diberi label dengan notasi perlakuan dan ulangan. Benih yang telah berkecambah dipindahkan kedalam gelas plastik yang dilapisi kapas. Setiap gelas berisi 2 kecambah.Selanjutnya kapas dibasahi dengan ekstrak air jarak pagar sebanyak 10 mL.Pengamatan variabel pertumbuhan dilakukan selama 12 hari setelah penanaman. Parameter yang diamati meliputi: daya kecambah, panjang tunas, berat segar akar, berat kering akar, berat segar kecambah, berat kering kecambah, rasio tunas akar, kandungan klorofil $a$, klorofil $b$ dan klorofil total. Daya kecambah dihitung dengan membagi benih yang berkecambah dengan total yang benih yang ditanam lalu dikalikan 100 .

Pengukuran panjang tunas dengan cara mengukur panjang tunas dari pangkal sampai ujung daun dengan penggaris dan dinyatakan dalam satuan centimeter $(\mathrm{cm})$. Pengukuranberat segar (tunas dan akar), dengan carabagian akar kecambah jagung dipisahkan dari tunasnya, dan masing-masing ditentukan berat segarnya dengan neraca digital. Berat segar dinyatakan dalam satuan milligram (mg). Pengukuran berat kering (tunas dan akar). Akar dan tunas yang telah diukur berat segarnya dikeringkan menggunakan oven selama 2 jam pada suhu $105-110^{\circ} \mathrm{C}$ untuk menghilangkan kadar air. Selanjutnya akar dan tunas ditimbang kembali dengan neraca 
digital dan dinyatakan dalam satuan milligram (mg). Rasio tunas akar dinyatakan sebagai perbandingan berat kering tunas dan akar.

Miazek menyatakan bahwa spektrofotometer pada panjang gelombang 648 dan $664 \mathrm{~nm}$, dapat mengukur absorbansi kandungan klorofil ekstrak daun (Indraswati, Zulkifli, dan Handayani 2017). Kandungan klorofil dinyatakan dalam miligram pergram jaringan dan di hitung menggunakan rumus :

$$
\begin{array}{ll}
\text { Chla } & =13.36 \mathrm{~A} 665-5.19 \mathrm{~A} 649\left(\frac{v}{w \times 1000}\right) \\
\text { Chlb } & =27.43 \mathrm{~A} 649-8.12 \mathrm{~A} 665\left(\frac{v}{w \times 1000}\right) \\
\text { Clhtotal } & =2.24 \mathrm{~A} 649-5.24 \mathrm{~A} 665\left(\frac{v}{w \times 1000}\right)
\end{array}
$$

Keterangan :

Chla : klorofil $a$

Chlb : klorofil $b$

A.664 : absorbansi pada panjang gelombang $648 \mathrm{~nm}$

A.668 : absorbansi pada panjang gelombang $644 \mathrm{~nm}$

$\mathrm{V}$ : volume alkohol

W : berat daun

Uji Levene merupakan uji untuk menentukan homogenitas ragam. Data pertumbuhan kecambah jagung varietas Bisi-18 dianalisis ragam pada taraf nyata 5\%. Jika perlakuan didapatkan hasil berpengaruh nyata maka dilanjutkan dengan uji BNT pada taraf nyata 5\%. Regeresi linier menentukan hubungan antara variabel bebas dan tidak bebas.

\section{HASIL PENELITIAN DAN PEMBAHASAN}

Daya Kecambah efek dari ekstrakdaun jarakpagar terhadap daya kecambah benih jagung hibrida varietas bisi 18 di tunjukan pada Gambar 1. 


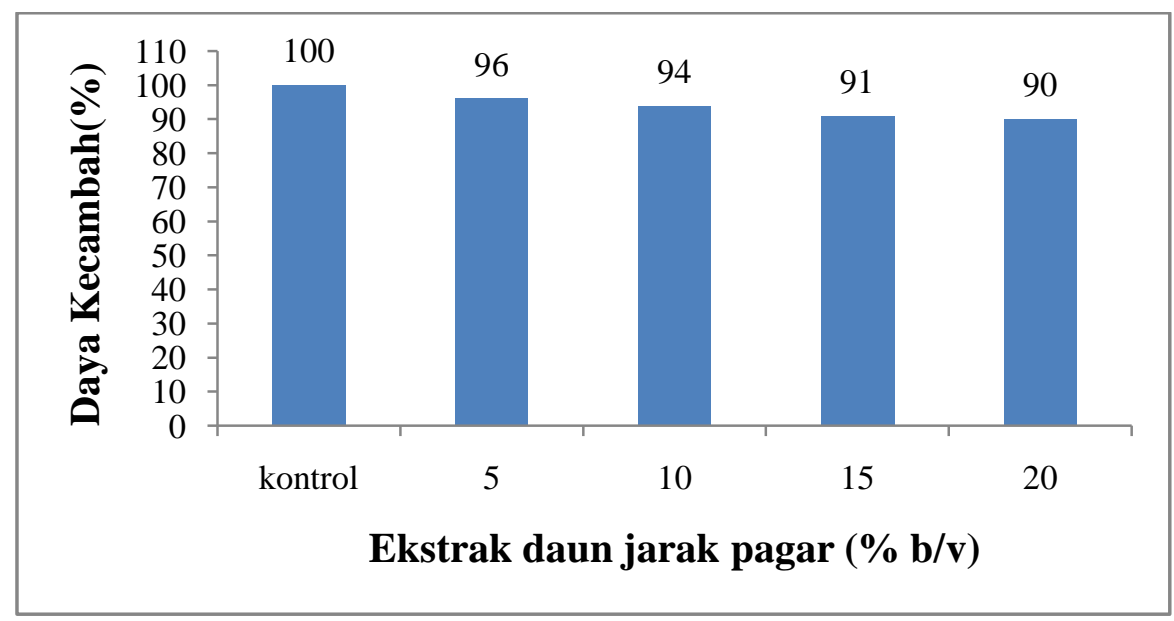

Gambar 1. Daya kecambah benih jagung hibrida varietas bisi 18 setelahdiberiekstrak daun jarak pagar

Grafik di atas menunjukan pertumbuhan daya kecambah benih jagung hibrida vartietas bisi 18 yang diberi perlakuan ekstrak daun jarak pagar dengan berbagai konsentrasi. Dapat dilihat bahwa pemberian ekstrak air daun kering jarak pagar sedikit berpengaruh terhadap perkecambahan benih jagung, bahwa semakin tinggi konsentrasi ekstrak jarak pagar maka persentase pertumbuhan kecambah menurun, dengan persentasi dari $90 \%-100 \%$.

Panjang Tunas Homogenitas ragam menggunakan uji Levene padatara fnyata 5\% menunjukan bahwa ragam ke lima tersebut homogen $(p-$ value $<0.05)$. Panjang tunas tanaman jagung hibrida varietas bisi 18 setelah pemberian ekstrak air daun kering jarak pagar disajikan pada Tabel 3. Analisis ragam pada taraf nyata 5\% menunjukan bahwa ekstrak daun jarak pagar berpengaruh nyata terhadap panjang tunas jagung hibrida varietas bisi 18 .

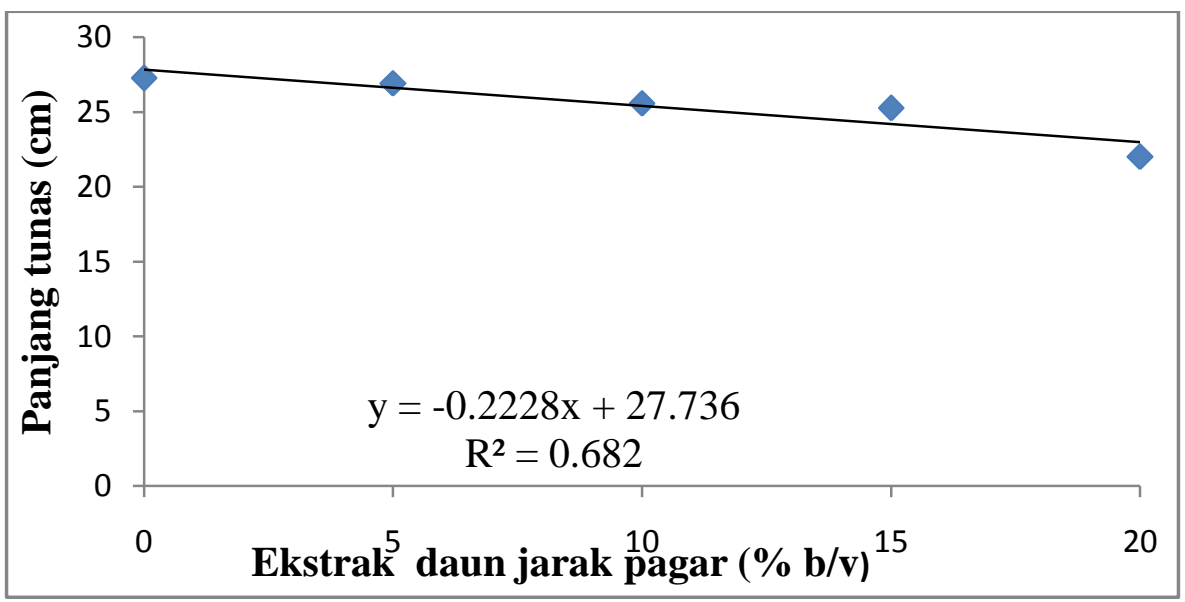

Gambar 2. Kurva Regresi Antara Ekstrak Air Daun Kering Jarak Pagar Dengan Panjang Tunas Kecambah Jagung Hibrida Varietas Bisi 18 
Analisis regresi menunjukan bahwa ekstrak daun jarak pagar berkorelasi linier negatif dengan panjang tunas jagung hibrida varietas bisi 18. Koefisien determinasi $\left(R^{2}\right)$ adalah 0.682. Koefisien korelasi $(r)$ adalah 0.83 yang menunjukan hubungan yang kuat antara ekstrak daun jarak pagar dengan panjang tunas kecambah jagung hibrida varietas bisi 18 .

Berat Segar Kecambah Homogenitas ragam menggunakan uji Levene pada taraf nyata $5 \%$ menunjukan bahwa ragam ke 5 tersebut homogen $(p-$ value $<0.05)$. Hasil analisis ragam pada taraf nyata 5\% didapatkan hasil yang tidak berpengaruh nyata $(p-$ value $<0.05)$ terhadap berat segar tunas, berat segar akar dan berat segar total

Berat Kering Kecambah Homogenitas ragam menggunakan uji levene pada taraf nyata $5 \%$ menunjukan bahwa ragam ke 5 tersebut homogen $(p-$ value $<0.05)$. Beratkering kecambah jagung hibrida varietas bisi 18 setelah pemberian ekstrak daun jarak pagar disajikan pada tabel 10. Analisis ragam pada taraf nyata 5\% menunjukan bahwa pemberian ekstrak daun kering jarak pagar terhadap berat kering kecambah jagung hibrida varietas bisi 18 berpengaruh nyata $p$ - value $<0.05$.

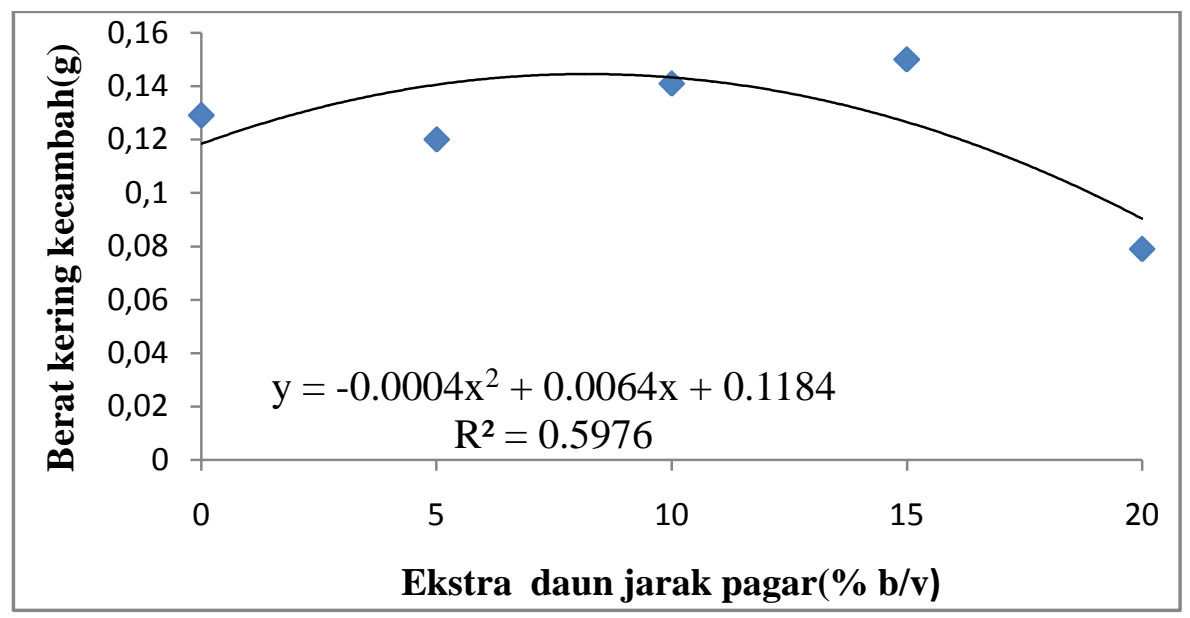

Gambar 3. Kurva Regresi Antara Ekstrak Daun Jarak Pagar Dengan Berat Kering Kecambah Jagung Hibrida Varietas Bisi 18

Analisis regresi menunjukan bahwa ekstrak daun jarak pagar berkorelasi kuadratik negatif dengan panjang tunas jagung hibrida varietas bisi 18. Koefisien determinasi $\left(R^{2}\right)$ adalah 0.5976. Koefisien korelasi $(r)$ adalah 0.773 yang menunjukan hubungan yang kuat antara 
ekstrak daun jarak pagar dengan panjang tunas kecambah jagung hibrida varietas bisi 18 . Konsentrasi optimum ekstrak air daun kering jarak pagar adalah pada konsentrasi $8 \%$ dengan nilai $X=8$ dan $Y=0.144$.

Rasio tunas akar Uji levene pada taraf nyata 5\% menunjukan bahwa ragam ke lima populasi pada tabel 6 adalah homogen $(p-$ value $<0.05)$. Analisis ragam pada taraf nyata $5 \%$ menunjukan bahwa ekstrak daun jarak pagar tidak berpengaruh nyata terhadap rasio tunas akar jagung hibrida varietas bisi 18 ( $p-$ value $<0.05)$.

Kadar Air Relatif Uji Levene pada taraf nyata 5\% menunjukan bahwa ragam ke lima populasi adalah homogen $(p-$ value $<0.05)$. Analisis ragam pada taraf nyata $5 \%$ menunjukan bahwa ekstrak daun jarak pagar tidak berpengaruh nyata terhadap kadar air relatif kecambah jagung hibrida varietas bisi $18(p-$ value $<0.05)$.

Kandungan Klorofil (Klorofil $\boldsymbol{a}, \boldsymbol{b}$, dan total) Uji Levene pada taraf nyata 5\% menunjukan bahwa ragam ke lima populasi adalah homogen $(p-$ value $<0.05)$. Analisis ragam pada taraf nyata 5\% menunjukan bahwa ekstrak daun tanaman jarak pagar tidak berpengaruh nyata terhadap klorofil $a$, klorofil $b$, dan klorofil total jagung hibrida varietas bisi $18(p-$ value $<0.05)$.

Pemberian ekstrak daun jarak pagar memberikan pengaruh negatif terhadap panjang tunas dan berat kering kecambah jagung hibrida varietas bisi 18. Pada variabel panjang tunas, efek ekstrak konsentrasi 5\%,10\% dan 15\% relatif sama dengan efek konsentrasi 0\%.Namun, pada ekstrak dengan konsentrasi $20 \%$ menunjukan penurunan panjang tunas sebesar $19.3 \%$ dari $27.26 \mathrm{~cm}$ menjadi $22 \mathrm{~cm}$. Hal ini sejalan dengan penelitian yang telah dilakukan oleh Rossi et al. yang melaporkan bahwa semakin tinggi konsentrasi ekstrak air daun jarak pagar, memiliki kecenderungan menurunkan panjang atau tingi tunas, jumlah daun, dan ukuran akar (de Rossi dkk. 2015).

Pada variabel berat kering pemberian ekstrak daun jarak pagar dengan konsentrasi $20 \%$ menurunkan berat kering secara signifikan sebesar $46.8 \%$ dari konsentrasi $10 \%$ dan sebesar $50 \%$ dari konsentrasi 15\%. Menurut Djafarudin senyawa alelokimia dapat menghambat proses 
pembelahan sel, pertumbuhan, dan sintesis protein yang terjadi pada tumbuhan (Senjaya dan Surakusumah 2008). Hasil penelitian ini sejalan dengan penelitian yang telah dilakukan oleh Khan menyatakan bahwa ekstrak daun jarak pagar pada konsentrasi 25\% secara signifikan menurunkan berat kering akar dan berat kering batang Parthenium hysterophorus L (Khan dkk. 2017).

\section{KESIMPULAN DAN SARAN}

Pemberian ekstrak daun jarak pagar lebih sensitif pada variabel panjang tunas dan berat kering kecambah, dan tidak mempengaruhi berat segar kecambah, rasio tunas akar, kadar air relatif dan klorofil jagung hibrida varietas bisi 18.

Perlu dilakukan penelitian lanjut tentang karakteristik alelopati ekstrak daun jarak pagar terhadap tanaman pangan lainya.

\section{DAFTAR PUSTAKA}

Heller, Joachim. 1996. Physic nut, Jatropha curcas L. Vol. 1. Bioversity international.

Indraswati, Debby Sarasmi, Zulkifli Zulkifli, dan Tundjung Tripeni Handayani. 2017. "Uji Ketahanan pada Kecambah Padi Gogo (Oryza sativa L.) terhadap Cekaman Kekeringan yang Diinduksi oleh Polietilen Glikol 6000.” Dalam Prosiding Seminar Nasional Teknologi Pertanian.

Junaedi, Ahmad, Muhammad Ahmad Chozin, dan Kwang Ho Kim. 2006. "Perkembangan terkini kajian alelopati." HAYATI Journal of Biosciences 13 (2): 79-84.

Khan, Asif Ullah, Faizan Ullah, Sultan Mehmood, Muhammad Irshad, dan Farhat Ullah Khan. 2017. "Allelopathic effects of Jatropha curcas L. leaf aqueous extract on early seedling growth of Parthenium hysterophorus L." Pakistan Journal of Agricultural Research 30 (1).

Raden, Ince, Bambang S. Purwoko, Edi Santosa, dan Munif Ghulamahdi. 2008. "Pengaruh Alelopati Jarak Pagar (Jatropha curcas L.) terhadap Perkecambahan Benih Jagung, Tomat dan Padi Gogo.” Jurnal Agronomi Indonesia (Indonesian Journal of Agronomy) $36(1)$.

Rosmarkam, Afandhie, dan Nasih Widya Yuwono. 2002. Ilmu kesuburan tanah. Kanisius.

Rossi, Eduardo de, Cleber Antônio Lindino, Reginaldo Ferreira Santos, Paulo André Cremonez, Doglas Bassegio, Willian Cézar Nadaleti, Jhonatas Antonelli, dan Fabíola 
Tomassoni. 2015. "Allelopathy effect of Jatropha curcas leaf extract on the radite." Journal of Food, Agriculture \& Environment 13 (2): 256-58.

Senjaya, Yusuf Andi, dan Wahyu Surakusumah. 2008. "POTENSI EKSTRAK DAUN PINUS (Pinus merkusii Jungh. et de Vriese) SEBAGAI BIOHERBISIDA PENGHAMBAT PERKECAMBAHAN Echinochloa colonum L. DAN Amaranthus viridis.(Potencies of Pine leaf Extract (Pinus merkusii Jungh. et de Vriese) as Bioherbicides for Gemination Inhibitor of Echinochloa colonum L. and Amaranthus viridis).” Jurnal Perennial 4 (1): 1-5. 